\title{
A Note on the Terminology of Painting in Old Uyghur
}

\author{
Jens Wilkens* \\ (Göttingen - Germany)
}

\begin{abstract}
Uyghur murals and miniatures are among the most frequently reproduced works of art in academic and popular books on the 'Silk Road'. However, written Old Uyghur sources about the process of painting are rare. In a text edited by Peter Zieme in 2017 and reprinted in a collection of his articles issued in 2020 the work of a skilled painter is described in a series of metaphors. The Old Uyghur manuscript found at Dunhuang preserves some Chinese technical terms in the form of loanwords. The article aims to elucidate the etymology of a hitherto unexplained verb and suggests the interpretation that the Uyghurs were familiar with the technique of pounces to sketch the outlines of a painting.
\end{abstract}

Key Words: Old Uyghur, Chinese, painting, pounces, Silk Road, Central Asian Buddhism, etymology, lexicography.

Özet: Eski Uygurcadaki Resim Terminolojisi Üzerine Bir Not Uygur duvar resimleri ve minyatürleri, 'İpek Yolu' ile ilgili akademik ve popüler kitaplarda en sık kopyası çıkarılan sanat

\footnotetext{
* Dr., Göttingen Academy of Sciences and Humanities, Jens.Wilkens@phil. uni-goettingen.de; ORCID: 0000-0002-5110-0533.

** I would like to express my gratitude to Hans Nugteren for reading a draft of the article and making valuable suggestions. I would also like to thank Peter Zieme for making his forthcoming article "Baumwolle und Indigo" (2022) accessible to me and Sarah E. Fraser for kindly sending me a copy of her 1999 article.
}

Received: 06.12.2021; $\quad$ Accepted: 17.12.2021; 
eserleri arasındadır; fakat resim yapma süreciyle ilgili yazılı Eski Uygurca kaynaklar pek nadirdir. Peter Zieme tarafindan 2017 yılında yayımlanmış ve 2020 senesinde makale külliyatında yeniden basılmış olan bir metinde yetenekli bir ressamın eseri bir dizi metaforla tasvir edilmiştir. Dunhuang'da bulunmuş olan Eski Uygurca el yazması, birkaç Çince teknik terimi ödünçleme sözcük şeklinde muhafaza etmiş̧ir. Bu makale, şimdiye kadar açıklanamayan bir fiilin etimolojisini aydınlatmayı amaçlamakta ve Uygurların, bir resmin ana hatlarını çizmek için delikli şablon tekniğine aşina oldukları yorumunu önermektedir.

Anahtar sözcükler: Eski Uygurca, Çince, resim, delikli şablon tekniği, İpek Yolu, Orta Asya Budizmi, etimoloji, sözlük bilgisi.

Introduction: Uyghur paintings are undoubtedly among the most well-known works of Central Asian art and are often reproduced in academic and popular works on the 'Silk Road'. As famous examples, the Manichaean miniatures on paper and the wallpaintings of Buddhist pranidhi scenes from the Bezeklik caves can be mentioned. A systematic investigation of Uyghur art has commenced only relatively late, culminating in the studies by Lilla Russell-Smith (2005) and Ines Konczak (2014). The former focused more on Dunhuang, while the latter dealt with the Turfan region.

References to the art of painting - sometimes understood as an act of devotion - are found occasionally in Old Uyghur Buddhist texts, e.g., in the Altun Yaruk Sudur ("Sūtra of Golden Light"; ed. Radlov \& Malov 1913-1917 folio 544.2-7). It is likely that the Uyghurs adopted not only motifs and complex pictorial programs from Chinese art - for instance the iconography of the Ten Kings of Hell - but also artistic techniques, tools, and materials as well as the corresponding terminology. That this was the case can be corroborated by a text published for the first time by Peter Zieme in 2017 and recently republished in his collection of articles (Zieme 2020) that he originally had made available on the platform academia.edu. In volume 47 of the series Berliner Turfantexte the 
highly important article is now numbered as text 27. This Old Uyghur text about the significance of the four Buddhist agamas was collected by Paul Pelliot at the famous cave no. 181 (in today's numbering: B 464) at Dunhuang (Zieme 2020: 185). The quite numerous interspersed Chinese characters are supposed to be pronounced as Old Uyghur words because suffixes can be attached to them according to the demands of Old Uyghur syntax and phonology. The system is similar to the manuscript from Dunhuang edited by Şinasi Tekin in 1980. Instances of confusion of dentals and sibilants in the manuscript point to its origin during the Yuan dynasty. On the verso of folio no. $15^{1}$ there is a longer passage describing how a painter creates a painting in successive steps. The passage continues until the recto of folio 16 . The whole description is metaphorical. ${ }^{2}$

\section{The text example}

While Zieme gives the Uyghur equivalents of the Chinese characters in brackets I will supply them in bold letters. ${ }^{3}$ The passage runs as follows according to the numbering of lines in the edition (Zieme 2020: 188-189):

014 或 azuča ärsär ymä bakțika tägmiš uz bädiz(015)čilär äybašlayu äyäyü lampukın yer tart(016)lap čizip 次 basa $^{4}$ anta yelimlig mäkä üzä (017) eyin čiẓip 復 ävirtimiz 三 üč ${ }^{5} \mathrm{~m}$

Acording to the pagination in Chinese characters.

2 The use of metaphors related to painting is quite restricted in Uyghur Buddhism. See the two examples in Kaygusuz 2021: 293 one which is from the text discussed here.

3 In the text quoted from Zieme's edition square brackets [ ] are used for damaged parts in the manuscript. Parentheses ( ) denote a vowel not written in the manuscript. Braces \{\} indicate a superfluous letter in the MS. In my translations of Old Uyghur phrases a subscript number 2 denotes a synonym compound.

4 No Old Uyghur equivalent is given in the edition. Perhaps the sequence in the manuscript is mistaken. The Chinese character 次 $c i$ has the Old Uyghur equivalents basa, anta basa, and munta basa in other texts (Wilkens 2021b: 113). I presume that one has to read anta 次 basa. This is the interpretation of line 024 of the manuscript (see footnote 9 ).

5 The Old Uyghur equivalent is missing in Zieme's edition. In the forthcoming article (Zieme 2022) $\ddot{u} c ̌$ was now added. 
(read: min) 四十種 kırk törlügläri ${ }^{6}$ (018) kațıšturmıš 法 nomlug boduglarıg öndü törön (019) mujadınčıg körk mäniz büțürür ärsär : 如是 munı munčulayu ${ }^{7}$ (020) ymä 經 sudurlug bakțika tägmiš yertinčü(021)lügtä yeg uzanmaklıg uz bädizčilär (022) 仏 burhanıg ömäklig sudurlug lampuk üzä (023) vainikelıg tınl(1)glarnıy köyüllüg 地 yerlär(021)in ${ }^{8}$ tarțlap anta 次 basa $^{9}$ birär 二 ikirär onar 法 nom(025)lug boduglarig ara katıšdurup ol bodug(026)larıg öndü törön temin ökči akıgsız (027) 五藴 beš ärkliglig ${ }^{10}$ muyadınčig körk mänizin bo (028) 經 sudur ičindä bütürür üčün $\{\check{c}\}\}^{11}$ anın birtin (029) üklimiš bošgut nom tep atanmıš ärür

Zieme (2020: 196) provides the following translation into French:

(014-018) Ou alors que des peintres efficaces qui ont attendu la bhakti premièrement et spécifiquement ont tracé et dessiné le lieu sur du papier indigo et, par conséquent, nous avons marqué ci-dessous avec de l'encre collée et [choisi] [parmi] 3040 (?) espèces de colorants de dharma. (018-029) $\mathrm{Si}$ on complète formes et figures merveilleuses en suivant la ligne directrice ${ }^{12}$ et la tradition, il en est ainsi : des peintres efficaces et pourvus de qualités supra mondaines qui ont attendu la bhakti du sūtra ont tiré et marqués les emplacements des vaineyika créatures avec l'indigo du sūtra de la méditation du Bouddha et après mélangé chacun, tous les deux, tous les dix des colorants de dharma et (en utilisant) ces colorants selon la ligne directrice et la tradition ils ont tout à coup accompli les figures merveilleux des cinq agrégats affranchis de contraints mondaines (sk. anāsrava) de ce sūtra. C'est le troisième, c'est pourquoi il est

6 Zieme has only [törlüg]läri. In Zieme 2022: [kırk tür]läri.

7 Perhaps we have to read Chinese 如是 ru shi as ančulayu or ančulayu ok. Both alternatives (ančulayu ymä and ančulayu ok ymä) are attested as equivalents for the Chinese phrase. See the glossary in Wilkens 2017: 247.

8 A reading oronlarin is also possible.

9 One has to assume that basa is the equivalent of 次 $\mathrm{ci}$. See footnote 4 .

10 ärkliglig is also attested as 根-lig. See Röhrborn 2017: 274.

11 I agree with the assumption in Zieme's (2020: 189) footnote 642 that üčünc in the MS is probably a mistake for $\ddot{u} c \ddot{u} n$. The immediately following anin points in this direction. The translation should then be corrected.

12 This is the translation for $\ddot{o} y d \ddot{u}$ which Zieme compares with $\ddot{o} y d i$ in the Kutadgu Bilig, a synonym of törö. 
nommé enseignement du dharma se multipliant [à partir] du nombre un.

\section{Discussion}

The quoted text which is extremely difficult to understand suggests that the Uyghurs were familiar with the Chinese terminology of painting. One possible loan originally read by Zieme (2020: 196, footnote 735) as lampok and identified as reflecting Chinese 藍寶 lan bao (LMC lam puaw') 'indigo (jewel)' is now convincingly explained by the same author in a forthcoming article as lampuk 'nainsook' (Zieme 2022), a term that appears in Turki and Modern Uyghur. The etymology is still unexplained. Still, Zieme (2022) considers with good reason a borrowing from Chinese. Thus the former interpretation that the text might refer to block-prints on indigo paper (Zieme 2020: 196, footnote 735) can no longer be sustained.

For the lexeme bakti we find the rendering "bhakti". We can assume that Zieme thought of the Sanskrit term bhakti for 'devotion' 13 but there is also the meaning 'division'. I accepted the etymology in my recent treatment of the lexeme (Wilkens 2021b: 99) but for the text quoted above I already suggested another possible etymology, namely a loan from Chinese 白綈 bai $t i$ (LMC pha:jk thiaj) ('white silk', i.e. 'painting surface'). Perhaps there were two distinct objects in Old Uyghur with two different etymologies: first, a paravent ('division') and second, a painting surface. Because the text in question is informed by Chinese artistic traditions I would now repeat my etymological suggestion of deriving at least the two examples from the description of painting in the Pelliot text from Chinese 白綈 bai ti, although it should be stated that the Chinese character 白 bai is usually reflected in Old Uyghur spelling as $\left\langle\mathrm{P}^{\prime} \mathrm{Q}\right\rangle$ and not as $\left\langle\mathrm{P}^{\prime} \mathrm{K}\right\rangle$ like in the Dunhuang manuscript under discussion. However, phonetically a spelling with $<\mathrm{k}>$ seems also possible. The phrase baktika tägmiš uz bädizčilär can be tentatively translated as "skilled painters who have a painting surface at hand". ${ }^{14}$

13 In his forthcoming article Zieme (2022) argues that both meanings of Sanskrit bhakti, namely 'line, stroke (as ornament)' and 'devotion' apply here.

14 In a Chinese draft of a work register reused in a mortuary context as a paper shoe from Turfan specifically trained 'painting masters' (畫師 hua shi) are 
In my opinion Peter Zieme's translation for the twice attested converb tartlap "(ils) ont tracé" is basically correct. ${ }^{15}$ Semantically, the verb must be a (quasi-)synonym of čiz-. However, the verb tartla- is not recorded elsewhere ${ }^{16}$ and it is perhaps possible to specify its exact meaning. If we attempt to segment the verb the common denominal suffix $+l A$ - likely explains the second syllable. Some Old Uyghur verbs in $+l A$ - have a foreign base (e.g., buyan+la-, nom+la-). Since there is no noun *tart in Turkic, ${ }^{17}$ it seems reasonable to suppose a foreign base. The evident Chinese background of the text suggests a Chinese etymology. The most likely explanation is to derive the base from 双 $d u o$ (LMC tuat) 'cut out; remove; prick' (Pulleyblank 1991: 85). ${ }^{18}$ The Uyghurs could not borrow the Chinese verb as a simple stem but had to add a verbal suffix. An exact morphological parallel can be adduced, namely the verb parla- 'to sprinkle, pour, splash' the base of which is Chinese 湀 po (LMC $p^{h}$ uat) (Wilkens 2021a: 553a). ${ }^{19}$ However, the phonetic side is different here. The loss of the syllable final $-t$ in parla- is maybe due to simplification because of the consonant cluster -rtl-. Old Uyghur has also a verb which does not preserve the consonantal coda: lala- 'to cut in two, to chop' borrowed from Chinese 刺 la (LMC lat) plus suffix $+l A$-. There is no explanation at hand why there are three different ways in Old Uyghur to render the consonantal coda $-t$ in Chinese loan words. In case of tartla- the underlying local pronunciation of the sequence [uat] in Chinese 㸚

mentioned (Fraser 1999: 387). Maybe the Old Uyghur term, although occurring in a much later text, reflects a similar official title.

15 tartlap is translated differently in the second instance "(des peintres) ont tirés". In his forthcoming paper Zieme (2022) opted for a different interpretation for both instances. He treats tartla- as having the same semantics as tart- 'to draw, pull'.

16 Menges (1955: 122) records the verb tatala- ( $\sim$ tatila-) 'to scratch' for Modern Uyghur. He suggests two possible etymologies: first, a loan from Mongolian tatala- and second, an intensive or frequentative formation *tart$a$-la- from tart- 'to pull'. The context of the Old Uyghur verb tartla- suggests that this verb is not related to the Modern Uyghur tatala-.

17 The onomatopoetic tırt recorded by Kāšgarī (Clauson 1972: 534a) can be ruled out in this context.

18 Kroll (2015: 97a) gives the following meanings: "1. cut off, cut away; pare away" and "2. pierce, prick". For Middle Chinese he reconstructs: tat.

${ }^{19}$ For a detailed discussion see Nugteren \& Wilkens forthc., section 2.4. 
$d u o$ could have been different from the one in 湀 $p o,{ }^{20}$ or, alternatively, tartla- may have been influenced by the inherited verb tart- 'to pull'.

If Chinese 叒 $d u o$ is indeed the correct etymon, we have possible evidence for the specific technique of perforated paper used as pounces studied in detail by Sarah E. Fraser $(1996,2000){ }^{21}$ Pounces from the walled up so-called library cave no. 17 at Dunhuang are impressive pieces of evidence for this artistic device. ${ }^{22}$ One specimen from the Pelliot collection in the Bibliothèque nationale de France, Paris, shows blue ink on the perforated paper (Fraser 1996: 60b, Fig. 1). As Fraser (1996: 60ab) has shown, sometimes an ink sketch of a figure was drawn on the paper before the ink outlines were perforated. Fraser (1996: 60b) describes the next step as follows: "In use, a pounce is set against the surface to be painted, and a bag of red powder is pounded over the holes, leaving a red dotted outline for the artist on the painting surface below". Originally I thought that, despite the well-attested use of red powder at Dunhuang, ${ }^{23}$ the Old Uyghur text might perhaps best be understood as referring to indigo powder (lampok) used for preparing the outline of the painting on the surface by means of a pounce. Now that Peter Zieme has suggested the new interpretation, lampuk probably refers to a small bag made of nainsook containing color powder. This first step of the artist is expressed here by the combined verbs tartla- čiz- in the first instance and tartla- alone in the second. Only then comes the next step: the underdrawing with ink with animal glue (yelimlig mäkä $\ddot{u z} \ddot{a}$ eyin čiz-). ${ }^{24}$ Then the colors (boduglar) are applied. It is most likely that different stages in the preparation of a painting are enumerated although the subject changes in the first sentence from

20 Erdal (1991: 380) discusses "the ejection of the dental at an early date in certain dialects" in yumurga vs. classical yumurtga. Whether such a scenario is plausible also for $l$ following $t$ as in parla- is difficult to say.

21 In both articles she deals also with sketches used in workshop settings.

22 In the collections with Dunhuang materials only 9 pounces are still extant (Fraser 2000: 197).

23 The pounces retrieved from Dunhuang still have traces of red powder (Fraser 2000: 197).

${ }^{24}$ Usually "pouncing is a substitute for underdrawing" (Fraser 2000: 195) but in case of the Old Uyghur text it is likelier to assume two successive preparatory steps. 
the third person plural to the first person plural due to the metaphorical context.

If the interpretation of the verb tartla- suggested above for the text found at Dunhuang is accepted, then the derivation from Chinese 叒 $d u o$ is remarkable, because a pounce in Chinese literature was usually called 粉本 fenben "powder version" (Fraser 1999: 380). ${ }^{25}$

As already mentioned, the overall context of the passage is metaphorical. The interpretation of the simile poses some difficulties, especially whether the use of the suffix $+l X g$ is in each case to be understood metaphorically. I would argue that we have to distinguish a metaphorical and a 'normal' attributive function. To name only the metaphors: "the colors of the dharma" (nomlug boduglar), "the painting surface of the sūtras" (sudurlug bakti $i$ twice), "the nainsook of the sūtras of buddhānusmrti" (burhanig ömäklig sudurlug lampuk), "the (painted) parts ${ }^{26}$ of the hearts of the living beings who are to be trained" (vainikelig tınl(i)glarnın köyüllüg yerläri), and "the admirable figures 2 of the five uncontaminated sense faculties" (aklgsiz beš ärkliglig mujadınčlg körk mäyiz).

Conclusion: The artist's practice of using pounces is not limited to Dunhuang. Two pounces were found at Karakhoto (Fraser 1996: 60c) and one with floral designs was collected in Karakhoja in the Turfan area (dated ca. to the 8th century; Fraser 1999: 380). ${ }^{27} \mathrm{We}$ have also an interesting observation in Grünwedel's account about the excavations at Toyoq Mazar where the Third Turfan Expedition worked from December 311906 until January 11 1907. To my

25 "Historically, the meaning of the word seems to have broadened from the designation of a concrete practice (i. e., pouncing) in its earliest stage to a later stage in the Tang when the word acquired the more general meaning of preparatory (or copy) sketch" (Fraser 1999: 380).

26 Perhaps to understood as 'outlines' here.

27 See also figures 2 (recto) and 3 (verso) in the same article. According to Fraser (1999: 384), paper cuts (also found in the Turfan region) have to be distinguished from pounces because they "are finished works rather than preparatory materials from which other objects would be produced”. 
knowledge, this passage has so far been overlooked in the discussion about pounces:

„Etwa auf halbem Wege bis zu der Talecke, wo die Hauptgruppe der Ruinen steht, liegt eine moderne Mühle. Unmittelbar neben oder vielmehr über dieser Mühle ist eine Ruinengruppe in einer Berghöhlung $L$. vom Flüßchen. Ausgrabungen an dieser Stelle ergaben Reste uighurischer Manuskripte und Bilder, darunter auch Papierpatronen zur Herstellung von Gemälden, welche wie die modern lamaistischen mit Nadeln vorgestochen waren." (Grünwedel 1912: 317).

Interesting is the context in which these pounces were found, namely together with Old Uyghur manuscripts and works of art. This context suggests that Uyghur artists were the ones who used these pounces.

Although conclusive evidence is lacking it seems reasonable to assume that Uyghur artists adopted the technique of using pounces with pricked outlines to produce works of art from trained Chinese specialists working at Dunhuang and perhaps also at Turfan. Although pounces were mainly used at Dunhuang to decorate ceilings within the caves (Fraser 1996: 60c), ${ }^{28}$ the Old Uyghur text shows that other painting surfaces were outlined with this technique as well.

28 Silk paintings were made with the help of preparatory sketches (Fraser 2000: 191). 


\begin{abstract}
Abbreviation
LMC Late Middle Chinese (reconstructions according to Pulleyblank 1991)
\end{abstract}

\title{
Bibliography
}

Clauson, Sir Gerard (1972): An Etymological Dictionary of PreThirteenth-Century Turkish. Oxford: Clarendon Press.

Erdal, Marcel (1991): Old Turkic Word Formation: A Functional Approach to the Lexicon. 2 vols. Wiesbaden: Harrassowitz (Turcologica 7).

Fraser, Sarah E. (1996): Régimes of Production: The Use of Pounces in Temple Construction. In: Orientations November 1996, 60-69.

Fraser, Sarah E. (1999): A Reconsideration of Archaeological Finds from the Turfan Region. In: 敦煌吐魯番研究 Dunhuang Tulufan yanjiu 4, 375-418.

Fraser, Sarah E. (2000): Formulas of Creativity: Artist's Sketches and Techniques of Copying at Dunhuang. In: Artibus Asiae LIX 3/4, 189-224.

Grünwedel, Albert (1912): Altbuddhistische Kultstätten in Chinesisch-Turkistan: Bericht über archäologische Arbeiten von 1906 bis 1907 Kuča, Qarašahr und in der Oase Turfan. Berlin: Georg Reimer.

Kaygusuz, Arzu (2021): Buddhistische Bildersprache in alttürkischen Texten: Eine literaturwissenschaftliche und philologische Analyse. Wiesbaden: Harrassowitz.

Konczak, Ines (2014): Pranidhi-Darstellungen an der Nördlichen Seidenstraße - Das Bildmotiv der Prophezeiung der Buddhaschaft Śākyamuni's in den Malereien Xinjiangs. $\mathrm{PhD}$ Dissertation LMU Munich.

Kroll, Paul W. (2015): A Student's Dictionary of Classical and Medieval Chinese. Leiden/Boston: Brill.

Menges, Karl Henrich (1955): Glossar zu den volkskundlichen Texten aus Ost-Türkistan II. Mainz: Verlag der Akademie der Wissenschaften und der Literatur in Kommission bei Franz Steiner (Akademie der Wissenschaften und der Literatur. 
Abhandlungen der geistes- und sozialwissenschaftlichen Klasse 1954, 14).

Nugteren, Hans \& Jens Wilkens (forthc.): Notes on Chinese Loanwords in Old Uyghur - Thirteen Etymologies.

Pulleyblank, Edwin G. (1991): Lexicon of Reconstructed Pronunciation in Early Middle Chinese, Late Middle Chinese, and Early Mandarin. Vancouver: UBC Press.

Radlov, Vasilij V. \& Sergej E. Malov (1913-1917): Suvarnaprabhāsa (sutra zolotogo bleska): Tekst ujgurskoj redakcii. Petrograd: Imperatorskaja Akademija Nauk.

Röhrborn, Klaus (2017): Uigurisches Wörterbuch: Sprachmaterial der vorislamischen türkischen Texte aus Zentralasien Neubearbeitung - II. Nomina - Pronomina - Partikeln. Vol.

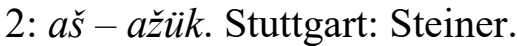

Russell-Smith, Lilla (2005): Uygur Patronage in Dunhuang: Regional Art Centres on the Northern Silk Road in the Tenth and Eleventh Century. Leiden-Boston: Brill (Brill's Inner Asian Library 14).

Tekin, Şinasi (1980): Buddhistische Uigurica aus der Yüan-Zeit. Wiesbaden: Harrassowitz (Asiatische Forschungen 69).

Wilkens, Jens (2017): The Uygur translation of the Chinese Bieyi zaehanjing 別譯雜阿含經 (Hedin Collection, leaves 12-15). In: Yukiyo Kasai, Simone-Christiane Raschmann, Håkan Wahlquist \& Peter Zieme (eds.), The Old Uyghur Āgama Fragments Preserved in the Hedin Collection, Stockholm. Turnhout: Brepols (Silk Road Studies 15), 197-280 (plates 23-30).

Wilkens, Jens (2021a): Handwörterbuch des Altuigurischen: Altuigurisch - Deutsch - Türkisch / Eski Uygurcanin El Sözlüğü: Eski Uygurca - Almanca - Türkçe. Göttingen: Universitätsverlag.

Wilkens, Jens (2021b): Uigurisches Wörterbuch. Sprachmaterial der vorislamischen türkischen Texte aus Zentralasien. III. Fremdelemente Band 1: eč - bodis $(a) v(a) t v$. Stuttgart: Franz Steiner.

Zieme, Peter (2017): Premières notes sur quelques fragments vieux-ouïgours de Paul Pelliot. First published on academia.edu December 2017.

Zieme, Peter (2020): Uigurorum veterum fragmenta minora. Turnhout: Brepols (Berliner Turfantexte XLVII). 
Zieme, Peter (2022): Baumwolle und Indigo. In: Bayarma Khabtagaeva (with the assistance of Zsuzsanna Olach) (eds.), Historical Linguistics and Philology of Central Asia: Essays in Turkic and Mongolic Studies. Leiden and Boston: Brill (The Languages of Asia Series 26), 238-248. 